\title{
糖オキサゾリンの一段階合成がもたらす構造明確な糖タンパク質合成
}

\author{
野口 真人；小林 厚志 ; 正田 晋一郎 \\ 東北大学大学院工学研究科バイオ工学専攻 \\ FAX: +81-22-795-7293, E-mail: shoda@poly.che.tohoku.ac.jp \\ （受付日：2015年3月20日, 受理日：2015年4月13日） \\ キーワード: 糖オキサゾリン誘導体，糖タンパク質，脱水縮合剤，エンド-N-アセチルグルコサミニダーゼ
}

\begin{abstract}
要 約
糖オキサゾリン誘導体は、 $N$-アセチルグルコサミニダーゼを触媒とする配糖化反応の優れた糖供与体となるこ とが知られている。本稿では、筆者らのグループにおいて開発された水溶性脱水縮合剤を用いる糖オキサゾリンの 一段階合成、ならびにそれらを供与体として用いる糖タンパク質に代表される複雑な構造をもつ配糖体の合成につ いて、最近の進歩を紹介する。
\end{abstract}

\section{A. はじめに}

哺乳類においては、発現タンパク質の半数以上が糖鎖に よる修飾を受けていると言われている。糖タンパク質の糖鎖 構造の違いによって、タンパク質の生理活性や安定性が大き く変化する。例えば、付加されたオリゴ糖鎖の構造が、タン パク質の品質管理機構に深く関与していることが近年の研究 により明らかになっている。これらの詳細については、以前 の TIGGを参照されたい (1-3)。

生体内での糖タンパク質合成は、多数の糖転移酵素と糖 加水分解酵素が関わる多段階の反応を経て達成される。この ため、糖鎖構造が完全に均一な糖タンパク質の合成は、高度 に制御された生合成システムをもってしても非常に困難であ る。現在のところ、糖鎖構造が完全に均一な糖タンパク質を 調製するためには、化学合成による手法を用いるか、あるい は化学-酵素合成による手法に頼るしかない。化学一酵素合成 法は、触媒である酵素がオリゴ糖基質および受容体となる夕 ンパク質部位を認識することができる限り、大きなオリゴ糖 を一気にタンパク質に導入することができる点において、化 学合成に比べ有利である。

化学一酵素合成法による糖タンパク質合成においては、 糖タンパク質に作用するエンド- $N$-アセチルグルコサミニ ダーゼを触媒として、糖オキサゾリン誘導体を糖供与体とし て用いることが多い。従来、糖オキサゾリンの合成には、ヒ ドロキシ基の保護と脱保護を伴う煩雑な多段階のステップが 必要であった。化学-酵素法による糖タンパク質合成を汎用 的な手法とするために、糖オキサゾリンのより簡便な合成法 の開発が強く求められている。本稿では、筆者らの研究室で 開発された水溶液中での糖オキサゾリンの一段階合成法を紹 介する。また、オリゴ糖オキサゾリンを供与体とする、加水 分解活性の低い変異型エンド-N-アセチルグルコサミニダー ゼを触媒とする糖タンパク質合成の技術革新について述べ る。

\section{B. 水溶性脱水縮合剤を用いるオキサゾリン合成}

糖オキサゾリン誘導体の合成は、対応するアセトアミド 糖の脱水縮合反応とみなすことができる（図 1)。筆者らは、 脱水縮合剂を利用することで水溶液中に扔ける糖オキサゾリ ン誘導体が合成可能ではないかとの着想を得た。この脱水縮 合反応を選択的に進行させるためには、アノマー位ヒドロキ シ基と、求電子率である脱水縮合剤が水溶液中で選択的に反 応することが必要である。グルコースのアノマーヒドロキシ 基の $\mathrm{p} K_{\mathrm{a}}$ 值は 12.4 と報告されており、水に比べてはるかに高 い酸性度を有している(4)。このため、グルコースなどのへ ミアセタール性ヒドロキシ基は、水溶液中で求核剤として反 応することが予想される。実際に、1995年には水-エタノー ル混合溶媒中、2,4,-ジニトロフルオロベンゼンを求電子剂と して用いるジニトロフェニルグリコシドの合成がS. Penadés らによって報告されている $(5)$ 。筆者らは水溶性脱水縮合剂 である1-エチル-3-(3-ジメチルアミノプロピル) カルボジイ ミド（EDC）を用いる糖オキサゾリン合成を試みた。その結 果、水溶液中で対応する糖オキサゾリンの合成が可能である ことがわかったが、反応条件の最適化を行っても収率は低い

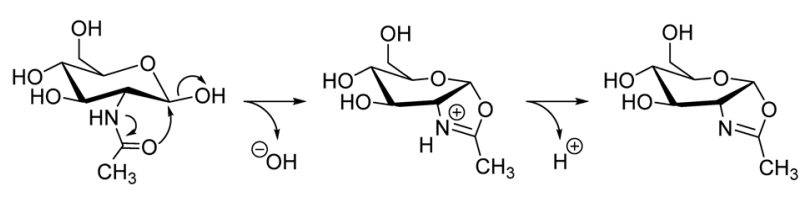

図 1．脱水反応によるオキサゾリン合成。

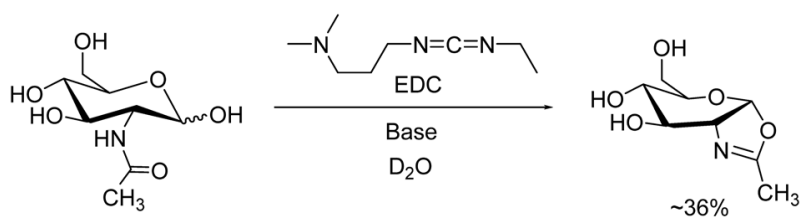

スキーム 1. 水溶性カルボジイミドを用いるオキサゾリン合 成。 
ものであった（スキーム1）(6).

EDC を用いる糖オキサゾリンの一段階合成では、カル ボジイミドの求電子性打よび中間体であるイソウレアの脱離 能の低さが、収率が低い原因であると考察した。収率向上の ため、種々の水溶性脱水縮合剤を検討した結果、ホルムアミ ジン型の脱水縮合剂である2-クロロ-1,3-ジメチルイミダゾリ ウムクロリド（DMC）が最もよい収率で糖オキサゾリンを 与えることを見出した。DMCが強力な脱水剤であることは、 アミドを分子内脱水して対応するニトリルに変換可能である ことからも明らかである(7)。

ここで開発した糖オキサゾリンの合成においては、

表 1. DMC を用いる糖オキサゾリン誘導体の合成。

\begin{tabular}{clrlll}
\hline & & & & \\
\hline
\end{tabular}

$\mathrm{DMC}$ とトリエチルアミンを過剩量用いることで目的とする 糖オキサゾリンを収率よく調製することができる（表1）(8）。 本手法は、 $N$-アセチルグルコサミンのような単糖だけでな く、N-アセチルラクトサミンやキトオリゴ糖などのオリゴ糖 にも適用可能であった。さらに、従来法では合成が達成さ れていなかった $\mathrm{N}$ 結合型糖鎖の一種であるジシアロオリゴ糖 も、シアル酸の脱離やラクトン化を伴うことなく対応するオ キサゾリン誘導体へと変換可能であった。得られた糖オキサ ゾリンは、キトオリゴ糖の場合は、逆相 HPLCで単離可能で あった。また、カルボン酸を有するジシアロオリゴ糖のオキ サゾリン誘導体の場合は、Sephadex G-15などの分取ゲルろ 過カラムを使用することにより精製可能であった (9)。ここ で開発したDMCを用いる反応は、保護・脱保護を含む多段 階経路による既存の方法で合成されるオリゴ糖のオキサゾリ ンの合成にも適用されている一般的性の高い方法論である (10-13)。

DMCによる還元末端選択的な直接活性化法は、オキサ ゾリン誘導体の合成だけでなく、さまざまな誘導体の合成に 適用された。たとえば、還元末端にグルコースを有する糖に $\mathrm{DMC}$ を反応させると、 1 位と 6 位の間で分子内脱水縮合反応 が進行し、対応する 1,6-アンヒドロ糖を合成することができ る(14)。さらに、アジ化ナトリウムあるいはアリールチオー ルの存在下で遊離糖にDMCを作用させた場合には、対応す るアジ化グリコシルおよびチオグリコシドへと効率よく変換 することができる（図2）(15-17）。

DMC 用いることで糖オキサゾリンの合成が水溶液中、 一段階で可能になったが、DMCの自発的な加水分解がかな り進行することから、低濃度の基質に適用する場合には、 DMC を過剩量用いる必要があった。またDMC は潮解性の高 い固体であるため、試薬の科量などの取扱が非常に煩雑で あった。さらに、DMCの分解物である1,3-ジメチルイミダゾ

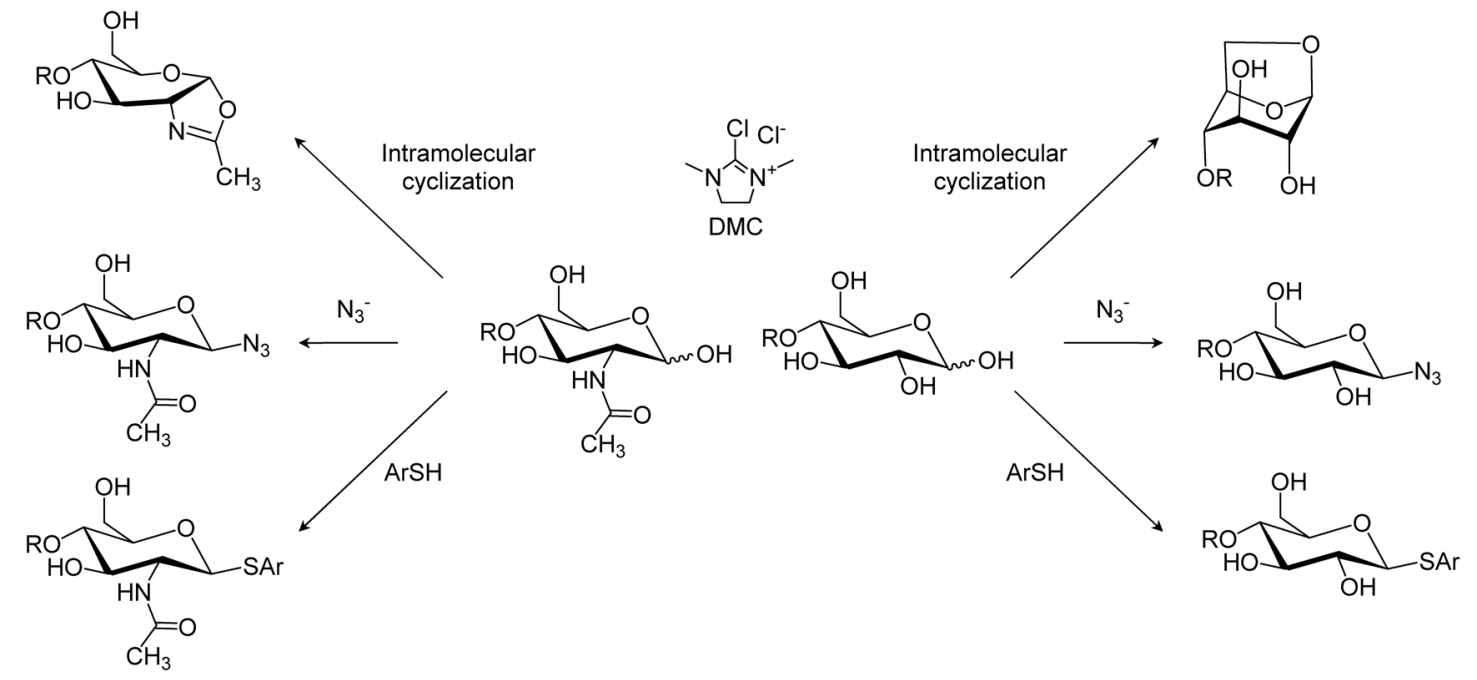

図2. 遊離糖のDMCによる誘導化反応。 
リジノン（DMI）は高沸点の極性溶媒であることから、水溶 液中からのDMIの除去は困難であった。筆者らは、これら の問題点を改善するために、DMC と同様の骨格を有するホ ルムアミジン型の脱水縮合剤の検討を行った。DMCでは活 性が強すぎることから、電子供与性基をホルムアミジン骨格 に導入することにより、試薬の安定性が向上するのではない

表 2. CDMBIを用いる糖オキサゾリン誘導体の合成。

\begin{tabular}{lllll} 
& & & \\
\hline & & & & \\
\hline
\end{tabular}

かと考えた。

筆者らは、DMCのエチレン部分をフェニレン基に置換 した2-クロロ-1,3-ジメチルベンズイミダゾリウムクロリド （CDMBI）を開発した(18)。CDMBIは潮解性を示さない安 定な固体であり、また、分解物である 1,3-ジメチルベンズイ ミダゾロンは水に難溶であることから、その除去が容易であ る。CDMBIの水への溶解性は室温において $1 \mathrm{~mL}$ の水に対し て $1.2 \mathrm{~g}$ 程度であった。このことから、CDMBIを脱水縮合剤 として用いた場合においても、水中において2-アセタミド糖 を対応するオキサゾリンに効率よく変換できることがわかっ た。 $150 \mathrm{mM}$ 程度の基質濃度の場合、同じ変換効率を達成す るのに必要な当量は DMC と変わらないが、 $50 \mathrm{mM}$ 以下の低 濃度領域で顕著な差が現れた（表2）。また、無機塩基であ るリン酸塩や炭酸塩を用いても、効率的に無保護糖をオキサ ゾリンへと変換可能であった。

CDMBI は、特に難溶解性のオリゴ糖や分子量の大きな オリゴ糖のオキサゾリン化に有効である。キトビオースを 用いて $1 \mathrm{mM}$ の濃度で 5 当量の CDMBI を使用した結果、収率 $30 \%$ 程度で対応するオキサゾリン誘導体が得られた（未発表 データ)。このように、CDMBIはDMCに比べて反応性が低 いものの、2-アセトアミド基とへミアセタール間の分子内脱 水反応により、対応するオキサゾリンを生成するに充分な活 性を有していることがわかった。分解物を沈殿として容易に 除去できるという利点を活かすことにより、オキサゾリン中 間体を単離精製することなく、出発原料からわずか二段階で
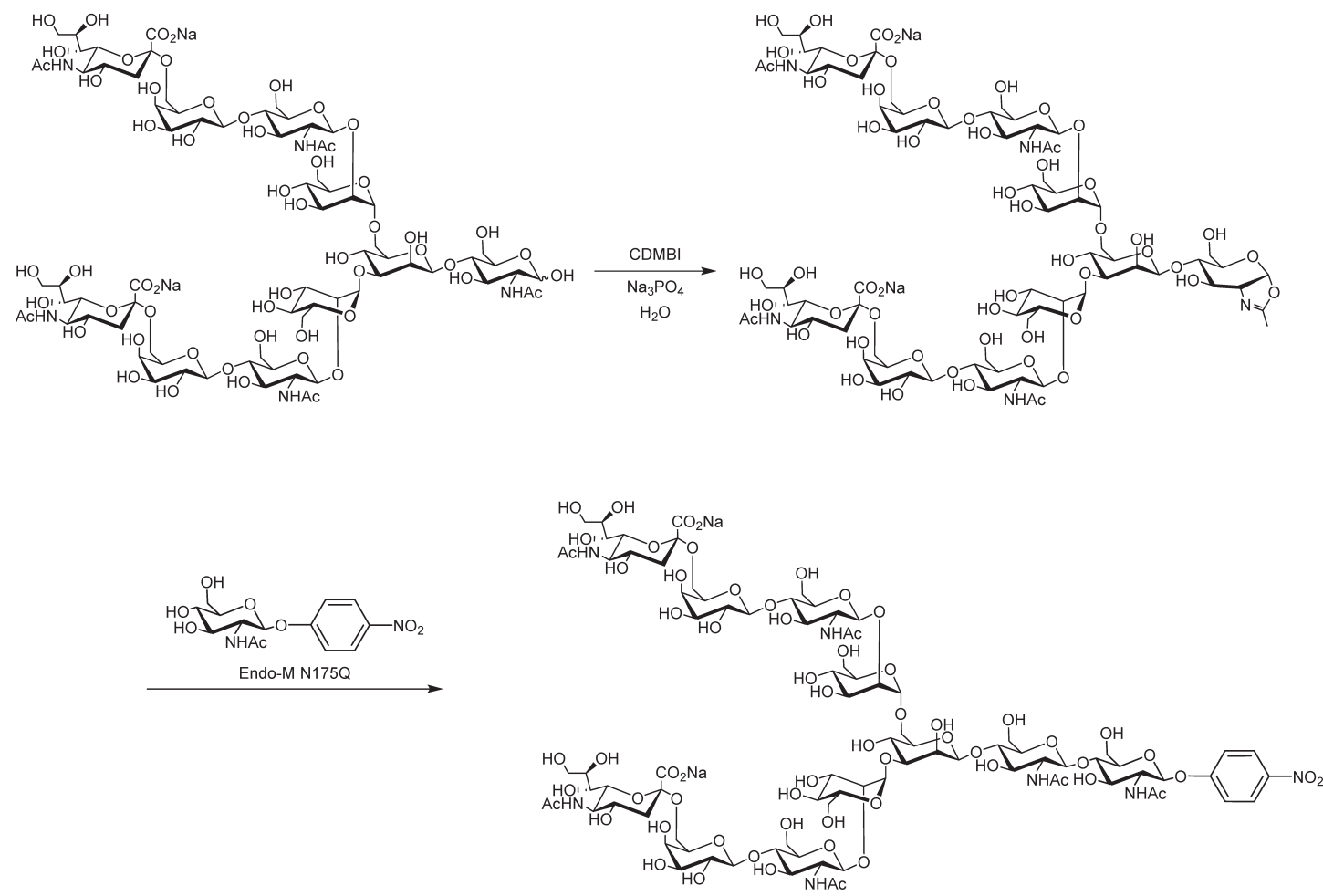

スキーム2. CDMBIによるオキサゾリン合成反応液を用いるEndo-M変異体触媒による単一溶液での配糖化反応。 
化学一酵素的配糖化を実現した（スキーム2）。

C. 糖オキサゾリンと変異型 $N$-アセチチルグルコサミニ ダーゼの組み合わせによる高効率な糖転移反応

一般に、糖加水分解酥素触媒による配糖体合成において は、糖転移生成物が酵素による加水分解を受けるため、収率 の向上が困難である。この問題の解決策の一つが Withers ら によって開発されたグリコシンターゼの利用である(19)。こ のグリコシンターゼは、アノマー保持型加水分解酵素の活性 サイトに存在する求核性アミノ酸残基を、非求核性アミノ酸 に置換することによって調製される。グリコシンターゼによ る配糖化反応では、目的とするグリコシド結合と逆の立体配 置を持つフッ化糖が糖供与体として用いられ、生成物の加 水分解を起こすことなく、好収率で対応する配糖体が得ら れる。詳細については、TIGGの以前の記事を参照されたい (20)。

Glycoside Hydrolase Family（GH）18や20、85に属する キチナーゼやへキソサミニダーゼ、エンド-N-アセチルグル コサミニダーゼなどの活性サイトには、求核性アミノ酸活性 残基が存在しない。これらの酵素によるグリコシド結合の加 水分解は、基質のアセトアミド基が求核剤として関与し、オ キサゾリニウムイオンを経由する “substrate assisted catalysis”と呼ばれる機構で進行する（図3）（21）。最近、オキサゾ
リニウムイオンのアナログである糖オキサゾリンを遷移状態 アナログ基質として用いる糖転移反応が数多く報告されてい る $(22,23)$ 。これらの酵素は、求核性アミノ酸を持たないた め、グリコシンターゼを調製することができない。糖転移能 力を向上させるためには、グリコシンターゼとは全く異なる 新しい戦略による変異導入が必要であった。

Bacillus circulans WL-12 由来のキチナーゼ $\mathrm{A} 1$ は GH 18 に 分類され、 $N$-アセチルラクトサミンのオキサゾリン誘導体を 認識する (24)。筆者らの研究室では、キチナーゼ $\mathrm{A} 1$ の-2位 のサブサイトに存在する 433 番目のトリプトファン残基をア ラニンに変異させることで、加水分解活性を消失させた変異 体（ChiA1 W433A）を取得した $(25,26)$ 。このChiA1 W433A はキチナーゼの活性測定試薬として沉用される $p$-ニトロ フェニル $\beta$-キトビオシドには作用しない。一方でこのChiA1 W433A は糖オキサゾリンを用いる糖転移活性は保持してお り、N-アセチルラクトサミンのオキサゾリン誘導体を糖供与 体、キトビオースを糖受容体とする配糖化反応が進行し、対 応する 4 糖を $96 \%$ の収率で得ることに成功した。これは、高 活性なオキサゾリン基質と低活性な糖加水分解酵素を組み合 わせ用いた初めての例である。また、ChiA1 W433Aを用い、 キトペンタオースオキサゾリン誘導体を糖供与体とし、キト ビオースを糖受容体とすることで、均一な難水溶性オリゴ 糖であるキトヘプタオースの合成に成功した（スキーム3）
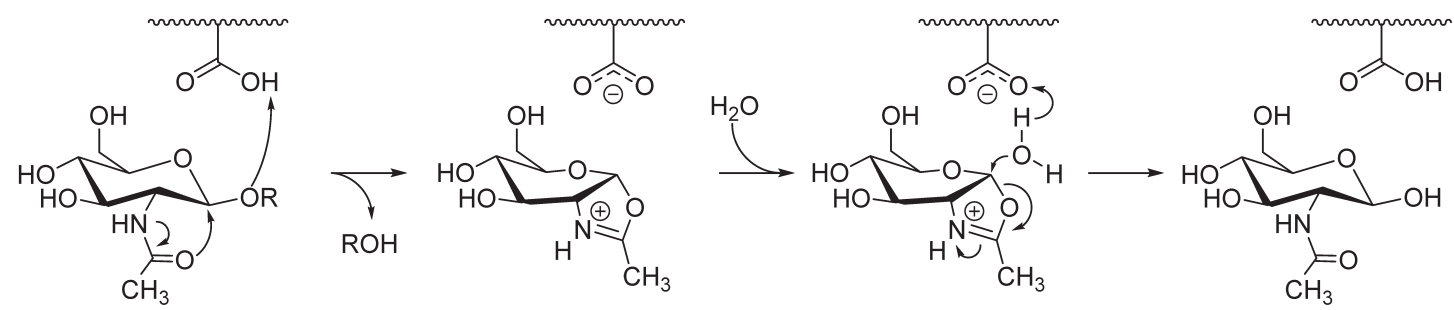

図3. “substrate assisted catalysis”機構で進行するへキソサミニダーゼの反応機構。

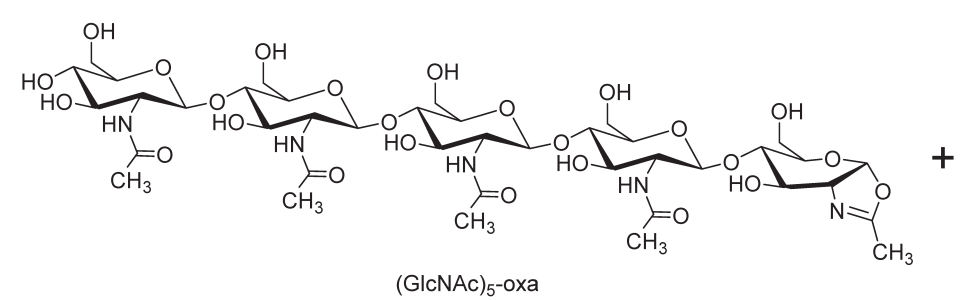

$(\mathrm{GlcNAc})_{5}$-oxa

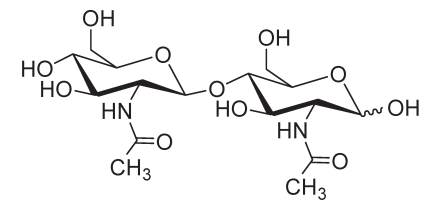

$(\mathrm{GlcNAc})_{2}$

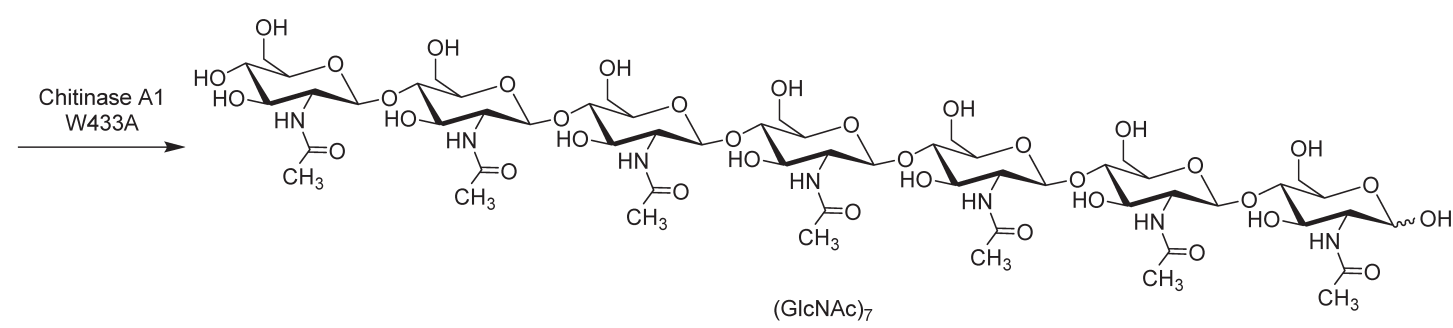

スキーム3. キトペンタオースオキサゾリン誘導体とキトビオースを基質とする低加水分解活性キチナーゼA1によるキトヘプタオー 久合成。 
（26）。このキトヘプタオースの選択的合成は、低加水分解活 性変異体の創出と、糖オキサゾリン誘導体の水溶液中での一 段階合成の達成により実現可能となった。

\section{D. 糖タンパク質合成への応用}

Mucor hiemalis 由来エンド- $N$-アセチルグルコサミニダー ゼ（Endo-M）は、GH85に分類される糖加水分解酵素である が、さまざまな N結合型糖鎖に作用し、GlcNAc-GlcNAc 間

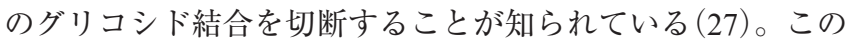
Endo-M は、適切な糖受容体の存在下に打いて高い糖転移活 性を示す。このことを利用して、シアル酸を含む糖ぺプチド が、ジシアログリコペプチド（SGP）を糖供与体として、合 成されている $(28-33)$ 。

Endo-M は二糖である Man-GlcNAcの糖オキサゾリン誘 導体も基質として認識し、GlcNAc受容体の存在下、糖転移 反応生成物を与えることがわかった(34)。興味深いことに、 三糖である Man-GlcNAc-GlcNAcは Endo-Mによって認識さ れないことが判明し、このことは糖転移生成物はEndo-Mに より加水分解されないことを示唆するものである。

最近山本らは、糖転移活性を向上させた低加水分解活性 変異体を開発している。217番目のチロシンをフェニルアラ ニンにした変異体（Endo-M Y217F）は、SGPを糖供与体と した場合、野生型と比較して、加水分解活性が $72 \%$ に減少 し、糖転移活性は $147 \%$ に上昇した (35)。このようにEndo-M Y217F はSGPを糖供与体として用いる糖転移反応の有効な触 媒となることがわかった。しかしながら、反応の進行ととも に、生成物の加水分解反応がかなり起きてしまうという問題 点が残されていた。

一方、175番目のアスパラギンをアラニンに置換した変 異体（Endo-M N175A）はSGPを加水分解する活性がほほ消 失しているにもかかわらず、糖オキサゾリン誘導体を認識 し、糖転移反応を進行させることがわかった。この 175 番目 のアスパラギン残基は、反応中間体であるオキサゾリニウム イオンを安定化する役割を果たすと考えられている（図4）。 このように 175 番目のアスパラギン残基変異体がオキサゾリ ン誘導体を糖供与体とする反応に有効であることがわかった ので、次に、他の変異体を調製し、加水分解や糖転移能を評 価した。その結果、175番目のアスパラギンをグルタミンに
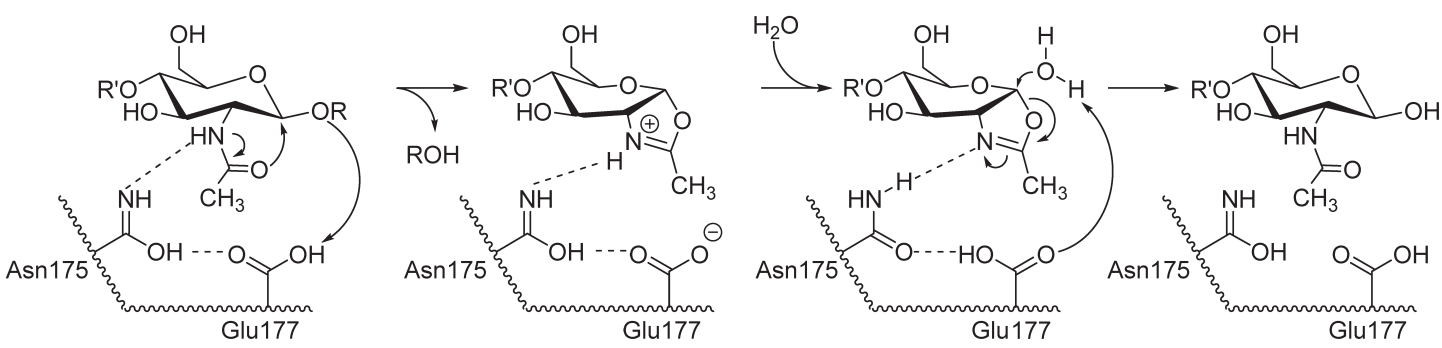

図4. Endo-Mによる加水分解反応におけるAsn 175 の役割。

変異させた Endo-M N175QがN-結合型オリゴ糖の転移反応に 最も適していることがわかった(36)。Endo-M N175Qを用い ることにより、オキサゾリン供与体の糖転移反応をほぼ定量 的に進行させることができ、さまざまな糖ぺプチドや糖タン パク質合成に応用されている(37-42)。Endo-M N175Qを触 媒として用い、CDMBI法により調製された不安定な反応中 間体である糖オキサゾリンを精製することなく、単一溶液 中での化学-酵素配糖化が実現されている（スキーム2）(18）. Endo-M N175Qは現在市販されている。

Endo-Mは、高マンノース型糖鎖や複合型糖鎖など幅広 い基質を認識するが、コアフコースを持つ $\mathrm{N}$-結合型糖鎖は 認識できなかった。これらの糖タンパク質の糖鎖をリモデ リングすることは困難と考えられてきた。Streptococcus pyogenes 由来エンド- $N$-アセチルグルコサミニダーゼ（Endo-S） はフコシル化された N 結合型糖鎖を認識することができる (43)。 B. G. Davis らのグループは、Endo-Sの基質特異性を利 用して、単一のグライコフォームを持つヒト $\operatorname{IgG} の$ 調製に成 功した。フコシル化されているヒト $\operatorname{IgG}$ にEndo-Sを作用さ せてFuc-GlcNAc-Asn構造へと変換した後に、 $\mathrm{Man}_{3}$ GlcNAc四 糖のオキサゾリン誘導体を用いてEndo-S を触媒とする糖転 移反応を行うことで、均一な糖鎖構造を有する $\operatorname{IgG}$ が調製さ れている(図5) (44).

またL.X. Wang らのグループは、Endo-Mにおける糖 転移能の効率化を基盤に、低加水分解活性を示すEndo-S を 調製した。Wangらは、233番目のアスパラギン酸をグルタ ミンまたはアラニンに変異させたEndo-Sが、オキサゾリン を基質とする糖転移反応を効率的に進行することを見出し た(45)。Endo-Sは、IgGに対して高い親和性を有しており、 $\mathrm{IgG}$ の糖鎖構造のリモデリングに極めて有用な酵素である (46)。

Streptococcus pneumoniae 由来エンド- $N$-アセチルグルコ サミニダーゼ（Endo-D）もまた、フコシル化されたN結合 型糖鎖を認識して切断することが知られている。このEndo$\mathrm{D}$ に関しても、Endo-Mの糖転移能の効率化における基本的 な戦略に沿って、変異体の開発が行われている(47)。これ まで紹介したエンド-N-アセチルグルコサミニダーゼ、EndoM、Endo-S、Endo-D はいずれも GH 85 に分類される糖加水分 解酵素である。このことから、糖オキサゾリンの一段階合成 

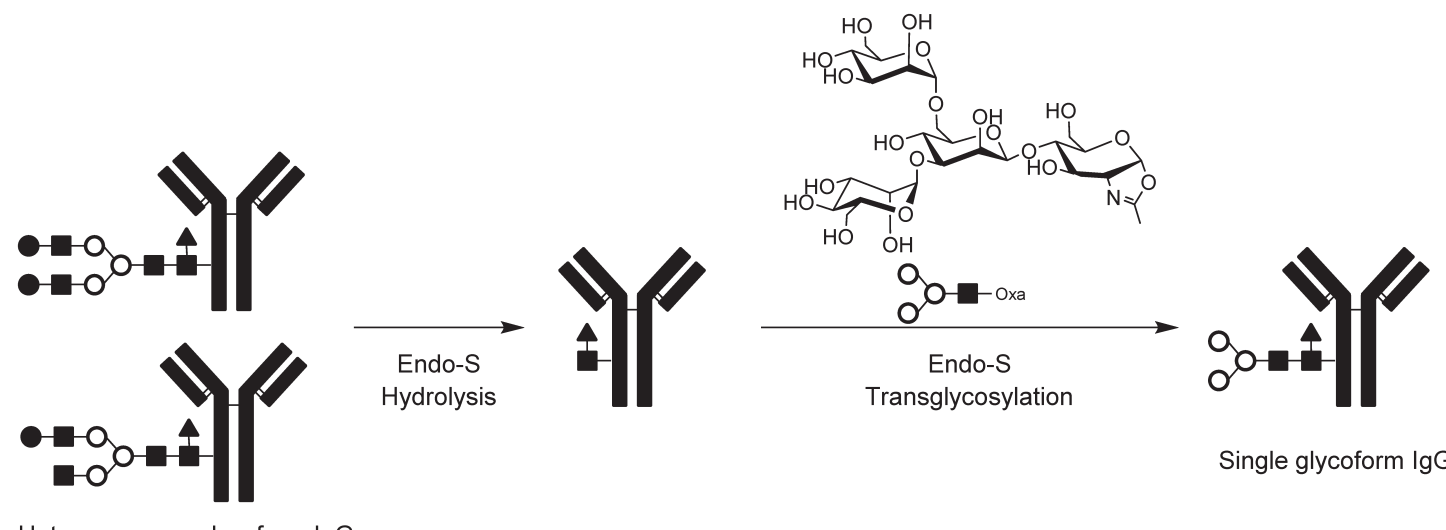

Single glycoform IgG

Heterogeneous glycoform IgG

図5. Endo-Sを用いる糖鎖リモデリング法による単一のグライコフォームを持つIgGの調製。

法は、糖鎖工学の分野において、多岐にわたるエンド-N-ア セチルグルコサミニダーゼに対して適用可能な一般的な合 成手法であることが示された。上述した変異型エンド- $N$-ア セチルグルコサミニダーゼを用いる糖転移反応については、 以前のTIGGに詳しく解説されているので、参考にされたい (48)。

\section{E. 今後の展望}

水中における糖オキサゾリンの一段階合成は、低活性グ リコシダーゼと組み合わせることにより、N-結合型糖タン パク質に代表される複雑な配糖体の合成に必要不可欠な基盤 技術となっている。しかし、その出発原料となるオリゴ糖 は、安価かつ大量に入手することが必ずしも容易ではない。 たしかに近年の単離技術の発展により、ジシアロ複合型糖鎖 （SGP）については、鷄卵卵黄から調製する強力な手法が開 発されているが(49)、将来に向けてより糖質科学の基礎研究 を推進するためには、これらオリゴ糖原料をより簡単に入手
することのできる体制づくりが期待される。

謝 辞

本稿で紹介した研究は、多くの共同研究者の協力により 達成されたものである。水溶液中での糖オキサゾリン誘導体 の一段階合成研究には、門川淳一教授（鹿児島大学）、田中 知成助教 (京都工芸繊維大学)、石原正規博士 (大塚化学)、 黄偉峻博士のほか多くの共同研究者の協力により行われてお り厚く御礼申し上げます。変異型Endo-Mを用いる糖転移反 応の研究には、共同研究者である山本憲二教授（石川県立大 学)、芦田久教授 (近畿大学)、梅川碧里助教 (立命館大学)、 Lai-Xi Wang 教授（Maryland University）に感謝いたします。 変異型キチナーゼの研究には、渡邊剛志教授 (新潟大学)、 桑折道済助教 (千葉大学) に感謝いたします。また、貴重な 糖鎖を提供頂きました北岡本光博士（食品総合研究所）、焼 津水産化学工業に厚く御礼申し上げます。

\footnotetext{
参考文献

1. Tanaka, K., and Fukase, K. (2012) Trends Glycosci. Glycotechnol. 24, 47-64.

2. Totani, K. (2010) Trends Glycosci. Glycotechnol. 22, 296-307.

3. Izumi, M., Kiuchi, T., Ito, Y., and Kajihara, Y. (2013) Trends Glycosci. Glycotechnol. 25, 1-12.

4. Thamsen, J., Lund, E. W., Åkerström, Å., Finsnes, E., Sörensen, J. S., and Sörensen, N. A. (1952) Acta Chem. Scand. 6, $270-284$.

5. Sharma, S. K., Corrales, G., and Penadés, S. (1995) Tetrahedron Lett. 36, 5627-5630.

6. Kadokawa, J., Mito, M., Takahashi, S., Noguchi, M., and Shoda, S. (2004) Heterocycles 63, 1531-1535.

7. Isobe, T., and Ishikawa, T. (1999) J. Org. Chem. 64, 6984-6988.

8. Noguchi, M., Tanaka, T., Gyakushi, H., Kobayashi, A., and Shoda, S. (2009) J. Org. Chem. 74, 2210-2212.

9. Huang, W., Yang, Q., Umekawa, M., Yamamoto, K., and Wang, L. X. (2010) ChemBioChem 11, 1350-1355.

10. Kumar, R. H. V., Naruchi, K., Miyoshi, R., Hinou, H., and Nishimura, S. (2013) Org. Lett. 15, 6278-6281.

11. Hojo, H., Tanaka, H., Hagiwara, M., Asahina, Y., Ueki, A., Katayama, H., Nakahara, Y., Yoneshige, A., Matsuda, J., Ito, Y., and Nakahara, Y. (2012) J. Org. Chem. 77, 9437-9446.

12. Amin, M. N., Huang, W., Mizanur, R. M., and Wang, L. X. (2011) J. Am. Chem. Soc. 133, 14404-14417.

13. Zou, G., Ochiai, H., Huang, W., Yang, Q., Li, C., and Wang, L. X. (2011) J. Am. Chem. Soc. 133, 18975-18991.

14. Tanaka, T., Huang, W. C., Noguchi, M., Kobayashi, A., and Shoda, S. (2009) Tetrahedron Lett. 50, 2154-2157.

15. Tanaka, T., Matsumoto, T., Noguchi, M., Kobayashi, A., and Shoda, S. (2009) Chem. Lett. 38, 458-459.

16. Yoshida, N., Noguchi, M., Tanaka, T., Matsumoto, T., Aida, N., Ishihara, M., Kobayashi, A., and Shoda, S. (2011) Chem. Asian J. 6, $1876-1885$.
} 
17. Tanaka, T., Nagai, H., Noguchi, M., Kobayashi, A., and Shoda, S. (2009) Chem. Commun. (Camb.), 3378-3379.

18. Noguchi, M., Fujieda, T., Huang, W. C., Ishihara, M., Kobayashi, A., and Shoda, S. (2012) Helv. Chim. Acta 95, $1928-1936$.

19. Mackenzie, L. F., Wang, Q., Warren, R. A. J., and Withers, S. G. (1998) J. Am. Chem. Soc. 120, 5583-5584.

20. Jakeman, D. L., and Withers, S. G. (2002) Trends Glycosci. Glycotechnol. 14, 13-25.

21. Scheltinga, A. C. T., Armand, S., Kalk, K. H., Isogai, A., Henrissat, B., and Dijkstra, B. W. (1995) Biochemistry 34, $15619-15623$.

22. Kobayashi, S., Kiyosada, T., and Shoda, S. (1996) J. Am. Chem. Soc. 118, 13113-13114.

23. Kobayashi, S., and Makino, A. (2009) Chem. Rev. 109, 5288-5353.

24. Shoda, S., Fujita, M., Lohavisavapanichi, C., Misawa, Y., Ushizaki, K., Tawata, Y., Kuriyama, M., Kohri, M., Kuwata, H., and Watanabe, T. (2002) Helv. Chim. Acta 85, 3919-3936.

25. Kohri, M., Kobayashi, A., Noguchi, M., Kawaida, S., Watanabe, T., and Shoda, S. (2006) Holzforschung 60, $485-491$.

26. Yoshida, N., Tanaka, T., Noguchi, M., Kobayashi, A., Ishikura, K., Ikenuma, T., Seno, H., Watanabe, T., Kohri, M., and Shoda, S. (2012) Chem. Lett. 41, 689-690.

27. Kadowaki, S., Yamamoto, K., Fujisaki, M., Izumi, K., Tochikura, T., and Yokoyama, T. (1990) Agric. Biol. Chem. 54, 97-106.

28. Haneda, K., Inazu, T., Mizuno, M., Iguchi, R., Yamamoto, K., Kumagai, H., Aimoto, S., Suzuki, H., and Noda, T. (1998) Bioorg. Med. Chem. Lett. 8, 1303-1306.

29. Yamamoto, K., Fujimori, K., Haneda, K., Mizuno, M., Inazu, T., and Kumagai, H. (1998) Carbohydr. Res. 305, 415-422.

30. Haneda, K., Inazu, T., Mizuno, M., Iguchi, R., Tanabe, H., Fujimori, K., Yamamoto, K., Kumagai, H., Tsumori, K., and Munetaka, E. (2001) Biochim. Biophys. Acta 1526, 242-248.

31. Saskiawan, I., Mizuno, M., Inazu, T., Haneda, K., Harashima, S., Kumagai, H., and Yamamoto, K. (2002) Arch. Biochem. Biophys. 406, $127-134$.

32. Fujita, K., and Yamamoto, K. (2006) Biochim. Biophys. Acta 1760, 1631-1635.

33. Tomabechi, Y., and Inazu, T. (2011) Tetrahedron Lett. 52, 6504-6507.

34. Fujita, M., Shoda, S., Haneda, K., Inazu, T., Takegawa, K., and Yamamoto, K. (2001) Biochim. Biophys. Acta 1528, 9-14.

35. Umekawa, M., Huang, W., Li, B., Fujita, K., Ashida, H., Wang, L. X., and Yamamoto, K. (2008) J. Biol. Chem. 283, $4469-4479$.

36. Umekawa, M., Li, C., Higashiyama, T., Huang, W., Ashida, H., Yamamoto, K., and Wang, L. X. (2010) J. Biol. Chem. 285, 511-521.

37. Umekawa, M., Higashiyama, T., Koga, Y., Tanaka, T., Noguchi, M., Kobayashi, A., Shoda, S., Huang, W., Wang, L. X., Ashida, H., and Yamamoto, K. (2010) Biochim. Biophys. Acta 1800, 1203-1209.

38. Asahina, Y., Kamitori, S., Takao, T., Nishi, N., and Hojo, H. (2013) Angew. Chem. Int. Ed. 52, 9733-9737.

39. Tomabechi, Y., Krippner, G., Rendle, P. M., Squire, M. A., and Fairbanks, A. J. (2013) Chemistry 19, 15084-15088.

40. Asahina, Y., Kanda, M., Suzuki, A., Katayama, H., Nakahara, Y., and Hojo, H. (2013) Org. Biomol. Chem. 11, $7199-7207$.

41. Tomabechi, Y., Squire, M. A., and Fairbanks, A. J. (2014) Org. Biomol. Chem. 12, 942-955.

42. Kowalczyk, R., Brimble, M. A., Tomabechi, Y., Faribanks, A. J., Fletcher, M., and Hay, D. L. (2014) Org. Biomol. Chem. 12, $8142-8151$.

43. Collin, M., and Olsén, A. (2001) EMBO J. 20, 3046-3055.

44. Goodfellow, J. J., Baruah, K., Yamamoto, K., Bonomelli, C., Krishna, B., Harvey, D. J., Crispin, M., Scanlan, C. N., and Davis, B. G. (2012) J. Am. Chem. Soc. 134, 8030-8033.

45. Huang, W., Giddens, J., Fan, S. Q., Toonstra, C., and Wang, L. X. (2012) J. Am. Chem. Soc. 134, 12308-12318.

46. Trastoy, B., Lomino, J. V., Pierce, B. G., Carter, L. G., Günther, S., Giddens, J. P., Snyder, G. A., Weiss, T. M., Weng, Z., Wang, L. X., and Sundberg, E. J. (2014) Proc. Natl. Acad. Sci. U.S.A. 111, 6714-6719.

47. Fan, S. Q., Huang, W., and Wang, L. X. (2012) J. Biol. Chem. 287, 11272-11281.

48. Wang, L. X. (2011) Trends Glycosci. Glycotechnol. 23, 33-52.

49. Sun, B., Bao, W., Tian, X., Li, M., Liu, H., Dong, J., and Huang, W. (2014) Carbohydr. Res. 396, 62-69. 


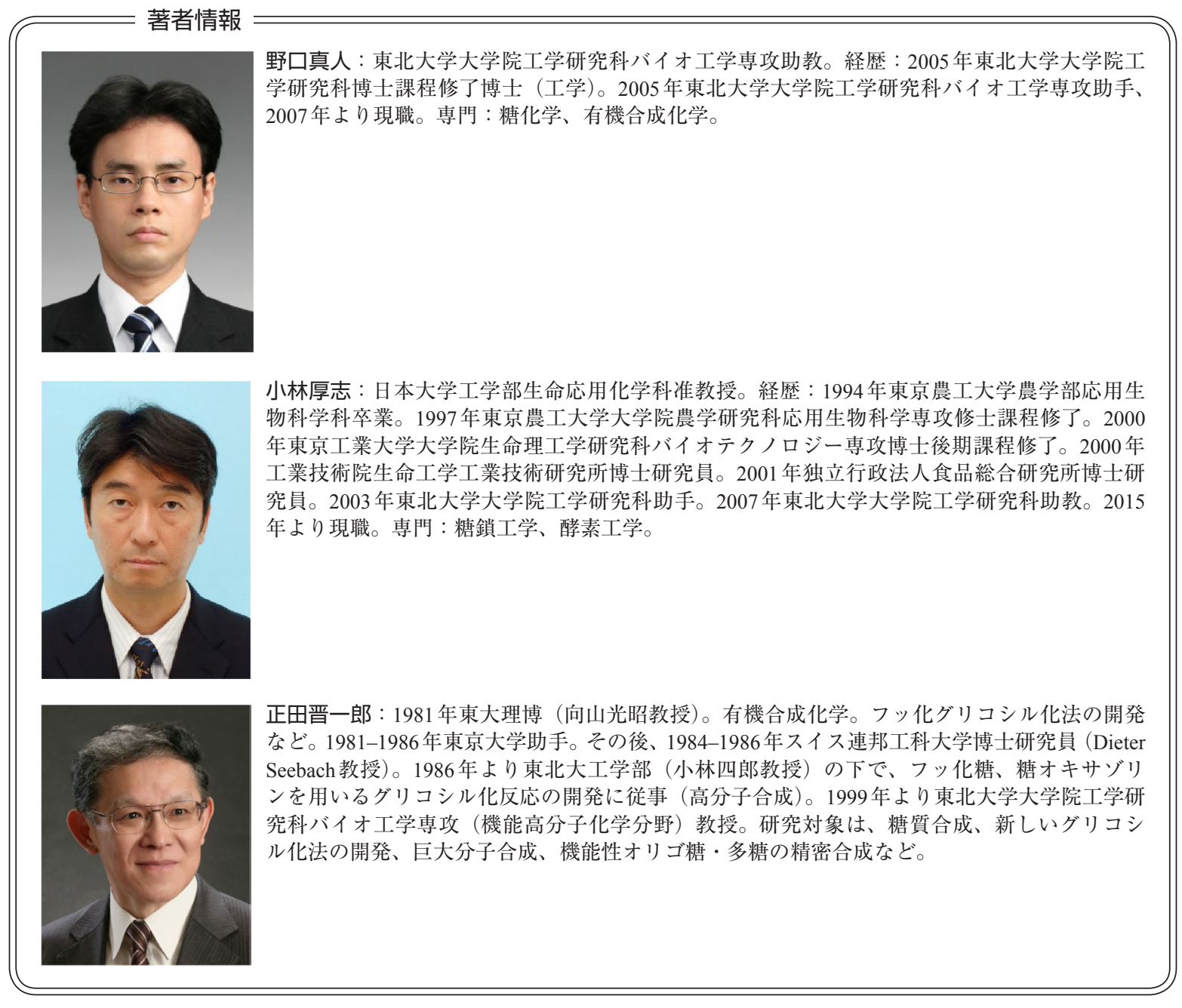

